\title{
Science Process skills analysis in children aged 4-6 years at Santa Lusia Medan Kindergarten
}

\author{
Nurmaniah $^{1}$, Risa Sianturi $^{2}$ \\ ${ }^{1,2}$ Lecturers of Early Childhood Education State University of Medan, Indonesia \\ nurmaniah@unimed.ac.id
}

\section{Abstract}

This study examined the skills of science process in children aged 4-6 years and became the formulation of this research, the problem is how science process skills of children aged 4-5 years and 5-6 years in Santa Lusia Kindergarten Medan. This research aimed to find out how science process skills of children aged 4-6 years in Santa Lusia Kindergarten Medan. The source of the research data was from teachers in kindergarten and the subject is in learning. Based on the initial survey, the research subject in this study was 20 children with 6 children as sample. Children aged 4-5 3 children consisting of 2 boys and 1 girl and for ages 5-6 3 children consisting of 2 boys and 1 girl that divided into 3 categories, which is a child who has Active, medium and low science process skills. The research methods used qualitative descriptive. The data collection techniques were done with an indepth observation and interview to the resource teacher, the teachers of the creative classroom Santa Lusia Kindergarten Medan. Data was analyzed by data collection, data reduction, data presentation, withdrawal of conclusions and verification.

The results showed that the skills of the science process demonstrated by children aged 4-6 years was medium category. Because of the 20 children who were observed only 5 children who had active skills of science processes and 12 children had medium science skills that last there are 3 children who belong to the low science process.
Keywords

process science; early

childhood

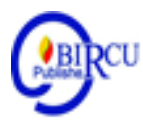

\section{Introduction}

The development of science and technology has progressed rapidly along with the changing times. Similarly, the development of science in education, which demands a change in the national education system so that people in particular early childhood can compete and adapt to the changes and developments of the current era and the Will come.

In early childhood education (PAUD), all aspects of children's development will be stimulated, both psychomotor aspects, language, cognitive, social-emotional, religious and Moral values (NAM) and art.

One of the most important aspects developed in children is the cognitive aspect. The scope of cognitive development of children is one of knowledge of science. According to Nugraha, Ali (2005:5) science can be seen as a process, as well as results or products, as well as attitudes. In other words, science is a unity of process skills, attitudes and outcomes. 
Science process skills are a skill to examine natural phenomena in certain ways to obtain information about the knowledge. According to Nugraha (2005:127) components of science process skills there are 12 namely: observing, classifying, measuring, describing, explaining, asking questions, formulating hypotheses, designing research, designing experiments, collecting data, Analyze data and draw conclusions.

The process of science allows children to explore objects, both living and lifelike objects around them. Children will find the symptoms of objects and the symptoms of events that exist in their surroundings. Science also trains children to use the five of their sensing to get to know different symptoms of objects and symptoms of events. The child acquires new knowledge of its interaction with the various objects surrounding it.

Based on the researchers ' observation, the child cause factor has low science process skills when teaching science teachers often using children's worksheets (LKA) or child magazines through cutting and pasting activities so that Children's science process skills are less developed, teachers never do outdoor learning, and learning media that teachers use is poorly prepared.

In the learning activities of the science process for children, teachers are required to teach with interesting and exciting methods of learning, the provision of learning media needed to conduct scientific experiments should also be prepared with Mature. Not only that, the design of interesting learning will also give rise to the child's interest to explore in developing science process skills so that children who do not understand the science process can directly engage in science activities that has been designed.

The problem that researchers pointed out, is almost similar to a research journal conducted by Septianingsih (2016) titled "Study of Basic science process skills in Group B Kindergarten children in cluster II district Kretek, Bantul", science process skills of those Children were still relatively low, so they were given the treatment by researchers applying experimental methods to improve the skills of the child's science process.

Based on the background outlined above, researchers were interested in conducting research activities titled "Analysis of Science process skills of children aged 4-6 years at Santa Lusia Kindergarten Medan".

\section{Review of Literature}

\subsection{Science Process Skills}

Dewi, Shinta (2009:154) defines the skills of a science process called the process of conducting activities related to the field of science. Science activities can be given to children in accordance with the development stages. For that, every teacher or educator of the PAUD should be able to understand the children's age-appropriate science activities. Another opinion expressed by Aisyah Laily (2014:4) that science process skills is an intellectual skill that is owned and used by scientists in natural phenomenon research, with the skills of science process then a scientist will Find facts and laws so that modern education is the skills of the science process more important than the mastery of products in the form of facts and principles of science.

Meanwhile, according to Nuryani and Andrian (Nugraha, 2005:125) defining science process skills are all necessary skills to acquire, develop, and implement concepts, principles, 
laws, and theories Science, whether in the form of mental skills, physical skills (manual), or process skills.

From some of these opinions, it can be concluded that science process skills are a fundamental way to obtain information about natural phenomena through direct observation or observation and through Simple science activities that can be a source of new knowledge for children. The science process skills in this research are fundamental science process skills that children can use to study science in concrete (real) form through various experiments or observations directly according to the stage Development of children.

\subsection{Science Process Skills Component}

The component of science process skills according to MURSID (2016:92) among them is the skill of observing with the whole senses, filing hypotheses, using tools and materials properly by always considering workplace safety, filing Question, classify, interpret, communicate the findings, dig and parse factual information to test ideas or solve daily problems. Meanwhile, according to Asrul and Syukri Ahmad (2016:238), the correct components of the science process skills are:

(a) Observe, that is to look carefully, (b) classify, i.e. the divide of several groups, (c) measuring, i.e. counting its size (length, large, spacious, tall, etc.) with certain tools, (d) outlines that are releasing The relationship of the parts of the parent or center, (e) Explaining the explained, elaborated, (f) asking important questions about nature, (g) Formulating a problem is to mention (conclude) a problem with Concise and precise, (h) formulating hypotheses i.e. mentioning (concluding) something that is deemed correct for a reason or a forewing of opinion even though its truthfulness remains to be substantiated (basic assumption), (i) designing investigations including experiments That is to create a system experiment and plan to prove the truth of a Theory, (j) Collect and analyze data, which is collecting data and conducting an investigation into an event to know the actual situation, $(\mathrm{k})$ Draw conclusions that are taking decisions obtained based on inducted or deductive thinking methods and so on.

In line with the opinion of Nuryadi Rustaman (in Nugraha Ali, 2005:127) classifying components of science process skills in more detail consisting of:

(a) The skills of the observing process (observation), (b) The process skills clarify (classify), (c) Process skills foresee (predict), (d) the process of communicating skills, (d) The skill of the use of tools and materials.

Of some components of the science process skills according to the experts that have been expressed above. So in this research component the science process skills that will be observed are the skills of observing, clarify, foresee, and communicate.

\section{3 Stages of Science Development for Children Aged 4-5 Years}

Sujiono $(2008: 12,21)$ revealed that the stages in science development of children aged 4-5 years consist of:

a. The child begins to use the picture to represent and reveal ideas. 
b. The child begins to think of explanations of what they care about, whether it is fact or imagination.

c. Start to be able to select the activities undertaken.

d. Initially the child experimented with working in a new laboratory then practiced the real place. For example children grow seeds in polybag or used plastic cups. Then after the seeds began to grow leaves, then the child will plant the seeds in a wider land for planting.

\subsection{Phase of Science Development for Children Aged 5-6 Years}

According to Sujiono $(2015: 10,19)$ phases of science development age 5-6 years consist of:

a. The child is able to plan research related to problem solving, such as when looking for answers how to breed animals. In this case, the research should be simple, allowing the child to be able to do so.

b. Can follow three stages of goal and enjoy some research directly from the teacher. First, the purpose of developing science learning is aimed at the introduction and mastery of facts, concepts, principles, theories and other aspects that exist in science. Secondly, the dimension of process science is aimed at mastering the skills necessary to explore and know science. Thirdly, the objectives of the Science Development Program are attributed to the science dimension as a gesture, the development of science learning in early childhood is pointed towards a personal formation or character. In this case, the child can develop himself to be open to the environment and able to use its development aspects in solving the problem faced, so that with the science of activities undertaken can improve His understanding of things happening around him.

c. Having intense attention to various science activities, they begin to enjoy the activities that are done within a few days. For example, when a child observes and measures the length of the plant stem from the first day, second, third, and after passing from a week.

d. Cooperate with five or six children. Able to follow the rules set in the group and want to listen to the ideas spoken by other members of the group.

e. Interested in books related to the activity of science practice with some illustrations of images.

f. Start to be able to understand the concept of science that is abstract but still with concrete real examples and direct practice.

g. Happy to use pictures and write the various experiences they get in the science practice that has been done.

\subsection{The Purpose of Learning Science in Early Childhood}

Here are some of the purposes of science learning in early childhood, which is expressed by some experts, namely: 
According to Mursid (2016:82) The aim of science in Early Childhood is (a) helping to foster an interest in learning and learning objects and events in their surroundings, (b) helping to understand and be able to describe concepts Science to explain the symptoms of nature and solve problems in everyday life, (c) Help to recognize and cultivate a sense of love to the environment so as to realize the majesty of the Almighty God.

In addition, according to Nugraha Ali (2005:29) argues that the purpose of science learning in early childhood is as follows:

(a) Assisting the child's understanding of the concept of science that relates to daily life, (b) helping to embed aspects related to the skills of the science process, so that the knowledge and ideas of the environment within the child Grow, (c) Help grow the child to know and study objects and events outside of their environment, (d) Facilitate and develop curious, diligent, open, critical, self-esteem, responsible, and independent in their lives, (e) Assisting children to be able to apply science concepts to explain natural symptoms and solve problems in everyday life, (f) Help the child be able to use simple technology that can Used to solve the problems found in everyday life, $(\mathrm{g})$ helping the child to be able to recognize and cultivate a sense of love for the environment, so as to realize the greatness and pride of the Almighty God.

From some of the above opinion on science learning objectives, it can be concluded that the purpose of science learning for early childhood is the child can increase knowledge and experience of children about the phenomenon and natural symptoms surrounding the child's environment Through diverse and enjoyable science learning and can assist the child in understanding and applying simple concepts of science so that children can solve the problems faced in daily life. The purpose of science learning in this research is to develop the skills of the child's science process through an active, creative and enjoyable learning method.

\section{Research Methods}

\subsection{Types of Research}

This research used a qualitative research type with a descriptive approach to find the information and gave an overview of the science process skills of children aged 4-6 years in the creative classroom Kindergarten Santa Lusia Medan and factors that caused children have high or low science process skills. The variables in this study were "analysis of science process skills of children aged 4-6 years at the SANTA LUSIA KINDERGARTEN. Data collection techniques were the most major step in research, since the main purpose of the research is getting data. The data collection techniques used in this study included observations and interviews.

In this study, researchers used interactive analysis models. Basically the interactive analysis model of the cycle-shaped process, which means that in this form researchers remain moving between three analytical components with the process of collecting data during the collection activities. After the data collection ended, the researcher moved between three components of analysis using the time. To obtain the validity of the data, the techniques used are: 1) improving diligence, doing more careful and continuous observation. By increasing persistence, researchers can re-check whether the data has been found to be incorrect or not. 
Likewise, by increasing diligence, research can provide an accurate and systematic data description of what is observed. 2) Triangulation technique, done by checking the data to the same source with different techniques. Data is obtained by direct communication and then checked with observations, questionnaires and documentation. The validity of data in the technique of triangulation using direct observation conducted by researchers with children and teachers, because it wants to get information about the skills of child science processes and teachers ' efforts in developing process skills Children's science.

\section{Discussion}

\subsection{Research Results}

The Data that had been obtained was collected and analyzed. Data on the skills of the children's science process was gained through observation and data on how teachers perform science learning activities to children found through live interviews with teachers.

Researchers did observations and interviews in Kindergarten Santa Lusia Medan. The observation was done on children age 4-6 years, the population were 20 children, from the total number of children, the sample were 6 children. Children age 4-5 3 children consisting of 2 boys and 1 girl and for ages 5-6 as many as 3 children consisting of 2 boys and 1 girl divided into 3 categories, they were children who had Active, medium and low science process skills. The six subjects were: Respondents A, B, C, D, E, F. Results showed that the subject has a high level of science process skills, i.e. a child active in the science process activities, the child with medium active and the child has Low science process skills. First, the active child was able to observe, classify, foresee and communicate the activities of the science process in a sequence. Secondly, the mediocre child was able to observe, classify but difficulty to predict what will happen in the activities of the science process that is being done and able to communicate the activities of the science process that has been done Simple. Third, children who have low science process skills are only able to observe science process activities but difficulty to classify, predict and communicate the activities of the science process performed.

Science process skills are a skill that is used to acquire data or information about phenomena or natural symptoms through simple scientific activities. Components of science process skills such as observing skills, classifying skills, predicting skills and communicating skills.

Science process skills children aged 4-6 years in Kindergarten Santa Lusia Medan divided into 3 namely children who are active, moderate and low. In the science process skills of children age 4-5 years and 4-6 years had a difference. In children age 4-5 years old child science process skills that were able to recognize the objects used for the experiment, the child was able to recognize the objects, the child was able to group objects, the child only guessed once in the science experiment Sinking eggs, drifting, floats and the child predicted that an egg can be drowned at the time of communicating the science activities that the child has finished being able to do. In children who had the skills of a science process that was capability of children to recognize the objects used for the experiment, the child is able to recognize the body of objects, the child is able to group several objects but some other objects the child has not been able to Group them, the child has not been able to guess what happens in the science activities that will be done and the child is able to retell the science 
activities that have been done but not all of them. Science process skills children who have low science process skills that are able to recognize the objects used for the experiments such as eggs, water, salt, aqua Cup but the child has not been able to recognize the objects, children have not been able to Classify objects used for experiments to be performed, the child has not been able to predict what happens in the science experiment activities conducted and for the activity of communicating the child has not been able to retell Completed science activities. Unlike children aged 4-5 years which is still a lot of children who have not been able to guess what will happen in science activities that will be in the teacher, in children aged 5-6 years of child science process skills are well developed Although there are children who still have low science process skills, this can be demonstrated from children who are active in science activities have the skills to recognize the objects that are used for the experiment, the child is able to recognize objects, children Able to group objects, the child is able to predict what is happening in the science experiment and the child is able to recount the science activities that have been completed and the child is able to answer the question of the teacher about the science that has been completed Done. In a child who has a skill that is not much different from a child active in the science process activity is to have the skills to recognize the objects used for the experiment, the child is able to recognize the objects, the child is able to group Variety, for the skill of predicting a child has not been able to do so and the child is able to retell the science activities that have been completed and able to answer the questions posed by the teacher after the science activities are done. And for the child who has the ability of a low science process that is able to recognize the object that is used for the experiment, the child is able to recognize the body of objects, the child is able to group 1 part flavor of 4 types of flavor, the child has not been able to guess what Happening in the science activities that will be done and the child is able to retell the science activities that have been done but not all if the teacher asks about the science activities that have been done by the child has not been able to answer it .

When children perform science process activities in the classroom, researchers observe and are strengthened by the results of researchers interviews with class teachers that the child has active science process skills because they are interested in science activities that Do, have a high curiosity, they have a desire to try, and they belong to a smart child in the classroom. For children who belong to the category of being interested in the science activities conducted, have a high curiosity, they have a desire to try but they are not a very clever child but they want to try. And the last child who belongs to the low category is a child who has less interest in science activities but because it sees his friend so that the child wants to ikutikutan doing science activities. The characteristic is reinforced by the characteristics of early childhood expressed by Sofia Hartati (2005:8-9) as follows: 1) has a great curiosity, 2) is a unique person, 3) love to fantasize and imagine, 4) a potential time to study, 5) has a egocentric attitude, 6) has susceptible to short concentration power, 7) is part of social creatures. Then, Rusdinal (2005:16) added that the characteristics of children aged 5-7 years are as follows: 1) Children in the pre-operationally, learning through concrete experience and with the instantaneous orientation and purpose, 2) children like to mention the names of objects that exist around it and define the word, 3) the child learns through spoken language and at this time develops rapidly, 4) Children need a more clear and specific structure of activities. 


\section{Conclusion}

Based on the results of research and discussion, it can be concluded that:

a. TK(Kindergarten) SANTA LUSIA is a private kindergarten school located in the province of North Sumatera, Deli Serdang. The school uses Catholicism as the main position of the religious education.

b. The results of the research conducted on children aged 4-5 years of active children's science process skills and those children were able to recognize the objects used for the experiment, the children were able to recognize the objects, the children were able to group objects, the children were only able to Guess once in the science of drowning egg experiments, drift, float and while communicating the science activities that had been done, those children were able to do it quite well though not sequential. For children who had mediocre skills of science process that children were able to recognize the objects used for the experiment, those children were able to recognize the body of objects, those children were able to group several objects but some other objects those children had not been able to Group them, the children had not been able to guess what happened in the science activities that would be done and those children were able to retell the science activities that had been done but not all of them. Children who had low science process skills were able to recognize the objects used for the experiments such as eggs, water, salt, aqua cup but the children had not been able to recognize the objects, children had not been able to Classify objects used for experiments to be performed, those children had not been able to predict what would happen in the science experiment activities conducted and for the activity of communicating the children had not been able to retell Science activities that had been done.

c. The results of the research done on children aged 5-6 years, children's science process skills had developed well even though there were children who still had low science process skills, this could be demonstrated from children who were active in science activities Having the skills to recognize the objects used for the experiment, those children were able to recognize the objects, the children were able to group objects, those children were able to predict what would happen in the science experiment and those children were able to retell science activities And those children were able to answer the teacher's question about the science that had been done. For those children who had mediocre skill that was not much different from a child active in the science process activity had the skills to recognize the objects used for the experiment, those children were able to recognize the objects, those children were able to group Variety objects, for the skill of predicting those children had not been able to do so and those children were able to retell the science activities that had been completed and able to answer the questions posed by the teacher after the science activities were done. And for those children who had the ability of a low science process were able to recognize the object that were used for the experiment, those children were able to recognize the body of objects, those children were able to group 1 part flavor of 4 types of flavor, those children had not been able to guess what would happen in the science activities that would be done and those children were able to retell the science activities that hd 
been done but not all, when the teacher asked about the science activities that had been done by those children, they had not been able to answer it .

\section{References}

Abruscanto, Joseph. (1995). Teaching Children Science a Discovery Approach. America: united States of America.

Asrul dan Syukri, Ahmad. (2016). Strategi Pendidikan Anak Usia Dini dalam Membina Sumber Daya Manusia Berkarakter. Medan: Perdana Publishing.

Aziz, Safrudin. (2017). Strategi Pembelajaran Aktif Anak Usia Dini. Yogyakarta: Kalimedia.

Dewi, Shinta. (2009). Keterampilan Proses Sains. Bogor: Regina.

Mursyid. (2016). Pengembangan Pembelajaran PAUD. Bandung: Remaja Rosdakarya.

Nana, Syaodih Sukmadinata. (2011). Metode Penelitian Pendidikan. Bandung: Remaja Rosdakarya.

Nugraha, Ali. (2005). Pengembangan Pembelajaran Sains Pada Anak Usia Dini. Jakarta: JILSI Foundation.

Septianingsih. (2016). Studi Keterampilan Proses Sains Dasar Pada Anak Tk Kelompok B Di Gugus ii Kecamatan Kretek, Bantul. FIP Universitas Negeri Yogyakarta. https://core.ac.uk/download/pdf/78028238.pdf . Accessed on June $28^{\text {th }} 2019$ at 22:10 WIB (western Indonesia time)

Sugiyono. (2013). Metode Penelitian Pendidikan Pendekatan Kualitatif, Kuantitatif, dan $R \& D$. Bandung: Alfabeta.

Sujiono, Yuliani Nurani. (2014). Metode Pengembangan Kognitif. Tangerang Selatan: Universitas Terbuka.

Susilaningsih, Budi. (2015). Peningkatan Keterampilan Motorik Halus Melalui Bermain Bubur Kertas Di Kelompok B Tk Aba Koripan, Srandakan, Bantul. FIP Universitas Negeri

Yogyakarta. https://eprints.uny.ac.id/26703/1/Budi\%20Susilaningsih\%20Skripsi.pdf . accessed on August $4^{\text {th }} 2019$ at $23: 30 \mathrm{WIB}$ (western Indonesia time)

Undang-undang no. 20 Tahun 2003 tentang Sistem Pendidikan Nasional. 